\title{
Abraham Maslow's Hierarchical Need Fulfillment and Herzberg's Two-Factor Theory for Creating Worker Loyalty
}

\author{
I Putu Artaya ${ }^{1}$, Made Kamisutara ${ }^{2}$, Achmad Muchayan ${ }^{3}$, IGA Sri Deviyanti ${ }^{4}$ \\ 1,2,3 Narotama University Surabaya, ${ }^{4}$ W.R. Supratman University Surabaya \\ 1putu.artaya@narotama.ac.id, 2made.kamisutara@narotama.ac.id, \\ 3achmad.muchayan@narotama.ac.id, ${ }^{3}$ srideviyanti@gmail.com
}

\begin{abstract}
This research was conducted in an attempt to identify and analyze the role and influence of two universally applicable theories in the life of an employee when working in a company. The research subjects are employees who work at the bank. The data collection model is carried out primarily using a questionnaire to explore their perceptions in creating and or maintaining a sense of loyalty in their workplace. To prove this, the researchers chose a bank that has been around for a long time, where there are 25 employees. We want to know whether Maslow and Herzberg's theory of motivation remains universally applicable in their work environment. This research is an associative study using the primary data base, this data from interviews and filling out questionnaires from the bank employees. Measurement of data using ordinal data with a Likert scale approach. From the results of filling out the questionnaire, the percentage results obtained that $71.4 \%$ of them tend to agree on the existence of their existence and fulfill their needs hierarchically. Through associative analysis, it can be obtained that the physiological results are $49.1 \%$ well fulfilled, sense of security is $47.4 \%$ fulfilled, social $43.8 \%$ is fulfilled, self-esteem $72.5 \%$ is fulfilled, and self actualization is $49.1 \%$ also fulfilled in the bank, this condition is enough to make their employees loyal in contributing energy, time and thoughts. Overall $93.7 \%$ of Maslow's hierarchical needs and Herzberg's maintenance are able to create a sense of employee loyalty to the workplace. The fulfillment of $72.5 \%$ hierarchical needs is dominated by the fulfillment of self-esteem, then in terms of maintenance theory, Herzberg is dominated by self-esteem and selfactualization.
\end{abstract}

Keywords: Fulfillment of needs, two factor theory, employee loyalty.

\section{INTRODUCTION}

In a developing society, humans have an increasingly important position, in a work orientation where we see work as something noble, then we do not mean neglecting the people who carry out the work. The view held by the community shows that this is the growing demand to pay attention to the human aspect and not only the technological and economic aspects of every business. Human resources are a very determining factor and have a large enough share, because they are the most important capital in driving the company's activities. In addition, employees also serve as the main tool for achieving the goals of the organization set by the company. For this reason, company management must be able to manage and utilize the potential of its employees optimally, in the sense that potential capabilities can be absorbed to an optimal level of work capacity, or at least close to supporting company activities in a more effective and controlled manner (Siagian, 1998).

To achieve this, companies and employees must be able to work together effectively. Meanwhile, to achieve effective cooperation, companies must be able to think about how employees can work 
with a strong will and high enthusiasm. Just as employees have certain desires that the company wants to fulfill, on the other hand, the company also has the desire that employees want to do this type of behavior. Therefore, it is the manager's job to motivate (direct) employees to be willing to carry out certain patterns of behavior that can support the company's success.

Given that human resources are a very important element, the maintenance of continuous and harmonious relationships with employees in every form of organization is very influential. The theory of human resources, in which there is an indication that an important part of the maintenance of this relationship, among others, concerns motivation and job satisfaction, counseling and the imposition of disciplinary unions, communication systems, organizational change and development as well as improving the standard of living of employees.

It is understood that the productivity of an organization is influenced by many factors, such as the opportunity to get additional education and training, the maintenance of good, rational and objective employees and most importantly a fair loyalty assessment. Therefore, the department that manages human resources absolutely needs to understand the problems that occur in an effort to maintain a harmonious relationship with the entire organization.

\section{Theoretical framework}

This theory emphasizes the importance of understanding the individual's internal factors, needs or motives that cause them to choose certain activities, ways and behaviors to satisfy their perceived needs. External factors, such as salary, working conditions, work relations and company policies regarding promotion, delegation of authority and so on, provide value or use to obtain positive employee behavior in an effort to achieve organizational goals.

\section{Abraham H. Maslow's Hierarchy of Needs Theory}

Quoting from Handoko's book (1992), Maslow is based on the concept of a hierarchy of needs on two principles. First, the needs of the needs that can be arranged in a hierarchy from the lowest to the highest needs. Second, a need that has been satisfied ceases to be the main motivator of behavior. According to Maslow, humans will be encouraged to fulfill their strongest needs according to time, circumstances and experiences following a hierarchy. In this level, the first needs that must be met first are physiological needs, such as remuneration, rest and so on. After the first needs are satisfied, the next higher needs will become the primary needs, this the need for security and a sense of security. The third need will arise after the second need is satisfied. This process continues until self-actualization needs are met, where management can provide incentives to motivate cooperative relationships, personal dignity, and a sense of responsibility to achieve high employee loyalty. For more details, Maslow's hierarchy of needs can be seen in the following figure: 


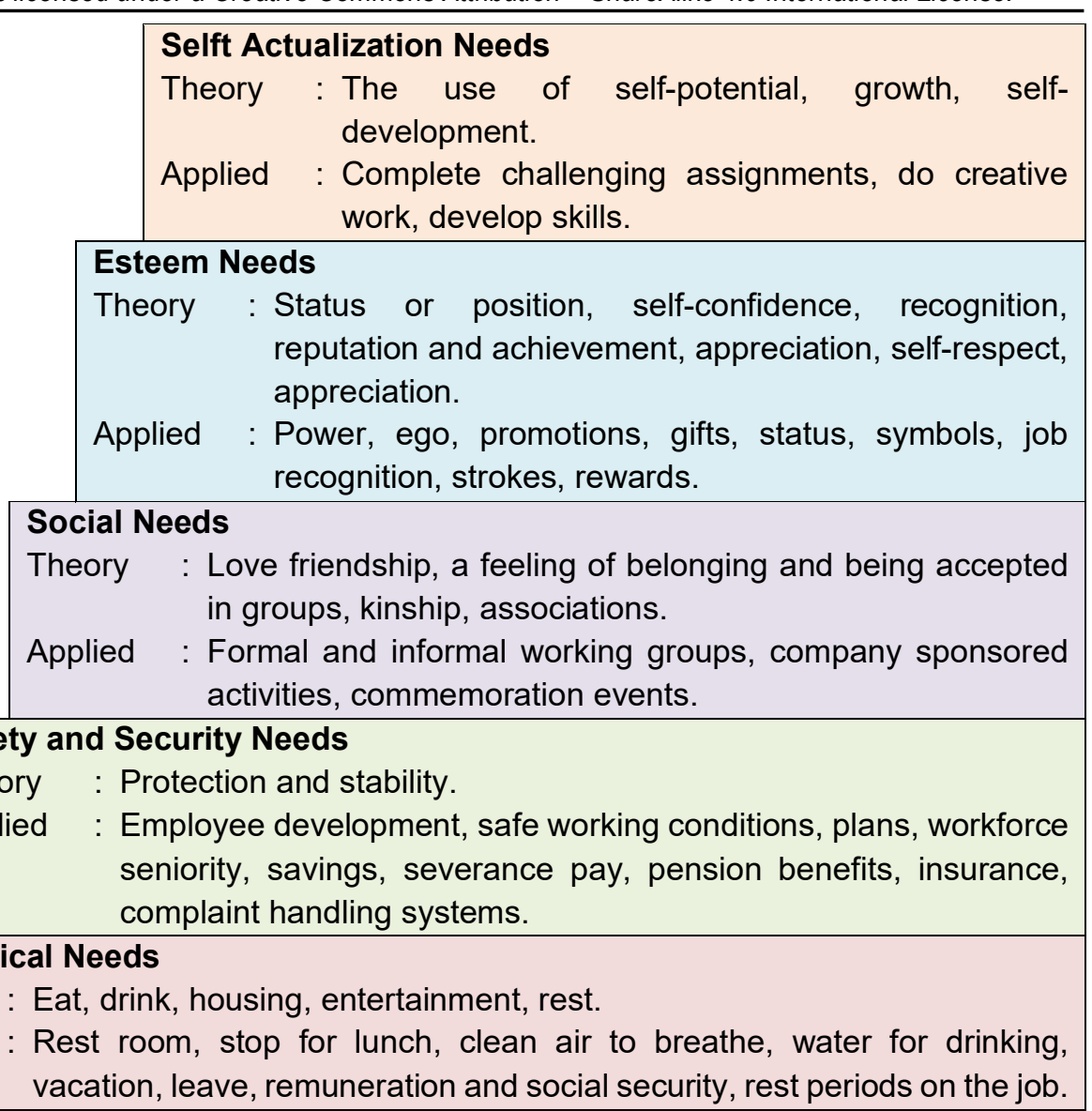

Figure 1. Maslow's hierarchy of needs, in theory and application as managerial motivation

\section{Herzberg's Acceptance Motivation Theory}

According to Handoko (1992), in general, new employees tend to meet lower needs at their first job, especially security. but once fulfilled, they will try to meet that level of need. higher such as the need for incentives and responsibilities. From the results of research conducted by Frederick Herzberg and his research group from the Pittshburg Psychological Service, there are two groups of factors that influence a person's job in an organization, this the job satisfaction factor which has a driving influence on loyalty and work morale, as well as a factor causing worker dissatisfaction (job dissatisfaction) which has a negative influence. Thus, researchers distinguish between what they call motivators or satisfaction and maintenance factors (sometimes called hygiene or dissatisfaction factors. Motivators have the effect of increasing loyalty or job satisfaction outcomes, whereas maintenance factors prevent moral decline, or increase efficiency. or eliminate job dissatisfaction but cannot be used as a source of job satisfaction that leads to the achievement of loyalty.

The theory of motivation and maintenance factors is parallel to Maslow's hierarchy of needs theory. Motivators are associated with self-actualization and respect, with lesser needs, especially security and security needs. For more details, see the following table: 
Table 1.

Factors of Satisfaction and Maintenance of Herzberg in Work

\begin{tabular}{|l|l|}
\hline \multicolumn{1}{|c|}{ Satisfaction Factors } & \multicolumn{1}{c|}{ Hygiene Factors } \\
\hline & Company policy and administration \\
Achievement & Quality controlling technique \\
appreciation & Work relationship \\
Creative and challenging work & Job status \\
Responsible & Worker safety \\
Progress and improvement & Personal life \\
& Payroll \\
\hline
\end{tabular}

Table 2.

Comparison between Maslow's Hierarchy of Needs Theory and Motivation Theory Herzberg hygiene

\begin{tabular}{|c|c|c|}
\hline Factors & $\begin{array}{l}\text { Maslow's hierarchy of } \\
\text { needs theory }\end{array}$ & $\begin{array}{l}\text { Herzberg's hygiene } \\
\text { motivation theory }\end{array}$ \\
\hline Motivational & $\begin{array}{l}\text { Self-actualization / self- } \\
\text { fulfillment and appreciation }\end{array}$ & $\begin{array}{l}\text { Creative and challenging work } \\
\text { Achievement } \\
\text { appreciation } \\
\text { Responsible } \\
\text { The odds increase } \\
\text { Progress }\end{array}$ \\
\hline Hygiene & $\begin{array}{l}\text { Social rewards } \\
\text { Security / sense of security } \\
\text { Physiological }\end{array}$ & $\begin{array}{l}\text { Status } \\
\text { Interpersonal relationships with } \\
\text { superiors, subordinates, } \\
\text { colleagues. } \\
\text { Company policy and } \\
\text { administration } \\
\text { Job security } \\
\text { Remuneration } \\
\text { Personal life }\end{array}$ \\
\hline
\end{tabular}

With the application of the two theories above to the scope and environment of workers, there is a tendency and goodness that can be felt directly by workers in building a sense of belonging, a sense of responsibility, a sense of togetherness and a sense of wanting to move forward when their work is actualized in their workplace on an ongoing basis.

\section{Modern-Day Worker Loyalty}

Researchers such as Argyris and Likert (Porter, 1995) criticize the human relationship model and propose a more specific model for utilizing employees. This model states that employees are motivated by many factors, not only money or the desire to achieve satisfaction, but also the need to excel and get meaningful jobs. They also reasoned that most people are motivated to do a good job and they don't automatically see work as unpleasant. They suggest that employees prefer fulfilling satisfaction from a good work performance. So, managers can use motivation, human relations, and human resources models simultaneously. With their subordinates, managers tend to apply human relationships. They try to reduce subordinate rejection by model improvement and satisfaction. For himself, managers will prefer the human resource model. They feel that their abilities are not being used fully, so they seek greater responsibility from their superiors. 
The definition of loyalty at work is one of the strongest human needs and Ranupandojo and Husnan (1993) always want to achieve. The term achievement (achievement), they interpret it as the meaning of the importance of a job, the level of skills required, progress and level of completion of a job. While Dharma (1997) defines what is done or a product or service produced or provided by a person or group of people. Here it can be concluded that loyalty is a condition in which someone feels they can complete their work and feels that the results of their work are needed by others, in other words that their work is valuable or important. In some cases, employee loyalty is really necessary for the implementation of the planned program, because the plans are neatly arranged without employee loyalty.

\section{METHOD}

This study only focuses on ten institution that is used as a place of research, and is used as a place for case studies in an effort to prove non-empirically about the associative relationship of variables. Through an associative model, the strength of one element in an equation can be predicted using other elements that are linear and proportional, and presented systematically through an equation, this the multiple linear regression model equation.

\section{Research Subjects}

The subjects in this study were employees of ten banks in the city of Surabaya, all employees became respondents in the data collection process, including the leadership. The questionnaire regarding the fulfillment of Maslow's hierarchical needs and the fulfillment of Hezberg's maintenance was filled in by employees, while the questionnaire on the measurement of employee loyalty was filled in by the leadership. Overall consisting of 250 respondents.

\section{Sampling Model}

Since all employees and leaders are respondents, the sampling model is census, not probability based. So that all employees at the ten banks have the same position and opportunity to become research samples.

\section{Data Collection}

In order to obtain adequate data in the analysis and discussion process, the researcher did not use secondary data collection, and the data collected was primary. This data is obtained from the results of filling out a questionnaire which is part of measuring employees' perceptions of variables related to employee loyalty.

\section{Data Analysis Model}

Because what is discussed and wants to estimate here is employee loyalty which is associated with several variables through an equation, the analysis tool used to analyze the data is the multiple linear regression equation. Where according to Sugiyono (2015), multiple linear regression equations can be formed through the following formulation:

$$
\mathbf{Y}=b 0+b 1 . \mathbf{X} 1+b 2 \cdot \mathbf{X} 2+b 3 \cdot \mathbf{X} 3+b 4 \cdot \mathbf{X} 4+b 5 \cdot \mathbf{X} 5+e
$$

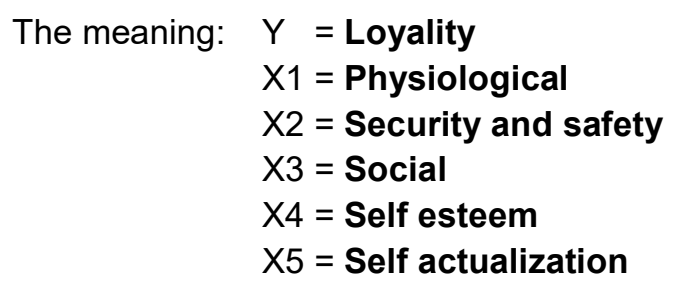


b0; The value is always constant without the influence of all forms of variance of the independent variable.

b1, b2, b3, b4, dan b5, is a regression coefficient that functions as an estimator value in the estimation process.

And, $e=$ is a confounding variable whose magnitude is not discussed in the model formed above and its value tends to be ignored.

The analytical tools above are only tools and serve as a basis for discussion, in making decisions and actions. Through the form and value of the five independent variables above, behavior and changes in employee loyalty variables can be predicted if the five variables experience changes in conditions randomly. Although the effect of the five independent variables is difficult to measure, at least through the estimation equation, the direction of movement can be seen.

\section{RESULTS AND DISCUSSION}

\section{Estimation Results of Regression Equations}

Based on the analysis process through the multiple linear regression analysis method, the independent variable group is used as a controlling or estimating variable or an estimation variable on the strength or value or magnitude of the dependent variable that has been formed in the regression model equation, the results of data processing or processing through analysis can be seen as shown below:

Tabel 3. Model Summary

\begin{tabular}{|l|l|r|r|r|rr|}
\hline \multicolumn{2}{|c|}{ Model } & $\mathrm{R}$ & $\mathrm{R}$ Square & Adjusted R Square & \multicolumn{2}{c|}{$\begin{array}{c}\text { Std. Error of the } \\
\text { Estimate }\end{array}$} \\
\hline & 1 &, $975^{\mathrm{a}}$ &, 950 &, 937 & &, 136 \\
\hline
\end{tabular}

a. Predictors: (Constant), Self-actualization, Social, Self Esteem, Security and safety , Physiological

In table 3 above, it is clear that the contribution of physiological, self of safety, social, self of esteem, and self actualization to employee loyalty is simultaneously $93.7 \%$ and the remaining $6.3 \%$ is caused by other variables outside the model. . This means that in this bank, the contribution of Maslow's hierarchy of needs motivation theory and Hezberg's two-factor theory of maintenance has a very big role in employee loyalty.

Tabel 4. ANOVA

\begin{tabular}{|rl|r|r|r|r|r|}
\hline \multicolumn{1}{|c|}{ Model } & Sum of Squares & \multicolumn{1}{c|}{ df } & Mean Square & F & Sig. \\
\hline 1 & Regression & 6,687 & 5 & 1,337 & 72,016 &, $000^{\circ}$ \\
& Residual &, 353 & 19 &, 019 & & \\
& Total & 7,040 & 240 & & & \\
\hline
\end{tabular}

a. Predictors: (Constant), Self-actualization, Social, Self Esteem, Security and safety ,

Physiological

b. Dependent Variable: Loyality

From table 4 above, it can be explained that through the Anova test it can be determined that all variables from Maslow's hierarchical theory and Herzberg's theory of maintenance have 
or are significant to employee loyalty. This can be seen from the Anova significance value whose value is lower than $5 \%$ in the Sig column.

Tabel 5. Coefficients

\begin{tabular}{|c|c|c|c|c|c|c|}
\hline & \multirow[t]{2}{*}{ Model } & \multicolumn{2}{|c|}{$\begin{array}{c}\text { Unstandardized } \\
\text { Coefficients }\end{array}$} & \multirow{2}{*}{$\begin{array}{c}\begin{array}{c}\text { Standardized } \\
\text { Coefficients }\end{array} \\
\text { Beta }\end{array}$} & \multirow[t]{2}{*}{$\mathrm{t}$} & \multirow[t]{2}{*}{ Sig. } \\
\hline & & $B$ & Std. Error & & & \\
\hline \multirow[t]{6}{*}{1} & (Constant) & $-1,030$ & ,314 & & $-3,276$ & ,004 \\
\hline & Physiological & 269 & 084 & ,282 & 3,191 & ,005 \\
\hline & $\begin{array}{l}\text { Security and } \\
\text { safety }\end{array}$ & , 192 & ,078 & , 186 & 2,475 & ,023 \\
\hline & Social & , 152 & ,066 & , 141 & 2,323 & ,031 \\
\hline & Self Esteem & ,411 & ,094 & ,348 & 4,380 & ,000 \\
\hline & Self-actualization & ,210 & ,074 & ,224 & 2,836 & ,011 \\
\hline
\end{tabular}

a. Dependent Variable: Loyality

From table 5 above, it can be seen about the significance or level of error testing for the $t$ test (partial), the overall value is below $5 \%$ (column Sig.), Which means that the five independent variables used in the model are physiological, security and safety, social, selt esteem., and partially self actualization all of them have a role and influence on the loyalty variable. The sign of the constant value in the betha column $(B)$ is negative, meaning that without meeting Maslow's motivation needs and Herzberg's motivation to maintain, there will never be loyalty to employees. The emergence of a loyal condition because employees feel that all the needs they want, their personal needs or individual needs, and the needs related to productive activities are considered when employees carry out and complete all kinds of work that become a burden and their duties at work If this goes in balance, of course there is a chance for creating a sense of loyalty to the employee concerned.

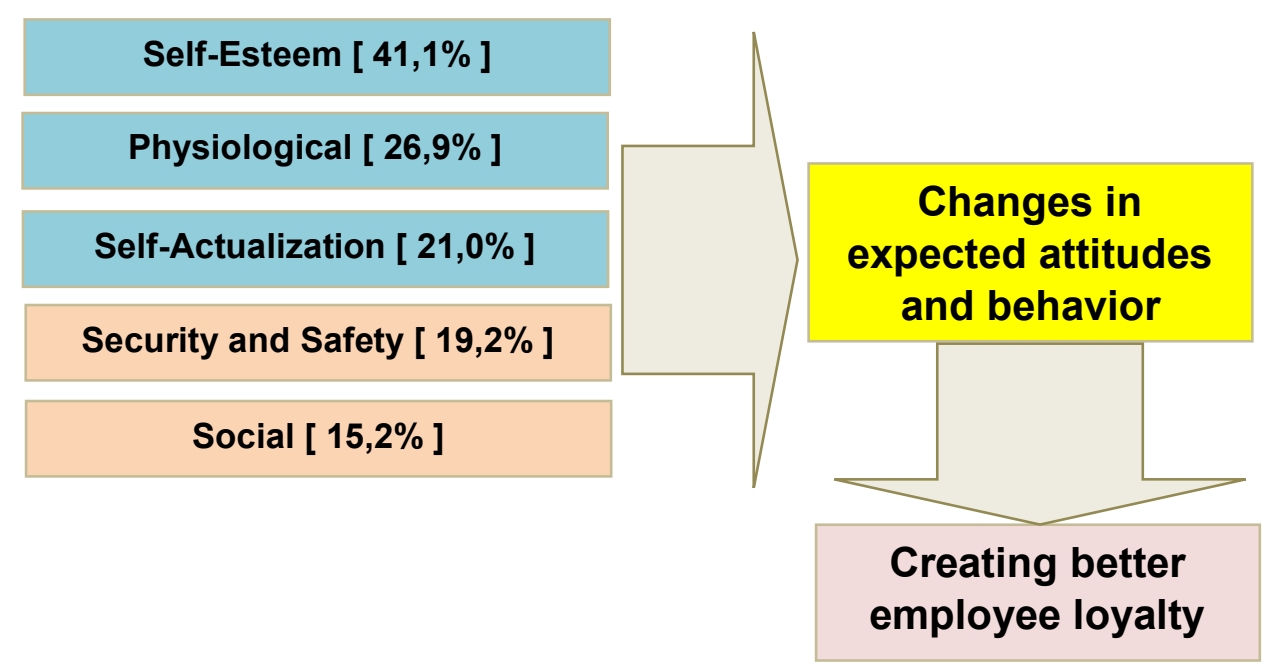

Figure 2. The estimation of behavior change based on an appreciation of the regression equation

Through the summary in table 5 , it is obtained the picture above, which illustrates the interaction of linkage between the independent variable and the dependent variable partially. The grouping of images above is taken based on the coefficient values of the variables in the regression estimation equation. Variables that have a coefficient of more than $20 \%$ are collected 
into one inseparable part, then variables that have a coefficient of less than $20 \%$ are grouped into one other section and separated from those with a coefficient of more than $20 \%$. This grouping will form two groups which can be said to be two factors. Variables that are grouped into two factors are called hygiene variables or loyalty maintenance variables. The reality of employees who work in banks say that in their perceptions self-esteem is important and the main thing for them when they carry out their duties and all kinds of work in the bank environment where they work. self-esteem is a recognition that has meaning and essence that is so important to them. A good self-esteem in their work environment will be able to create a sense of confidence that they are useful for the bank, this condition triggers job loyalty. Four other variables not discussed are supporting variables for self-esteem in an effort to create loyalty for employees. The two groups of variables shown in Figure 2 above are two interrelated and complementary strengths and are needed as nurturing variables for the creation of a good work environment to maintain loyalty. The self-esteem variable is above with a coefficient of $41.1 \%$ which means that to maintain employee trust in ten banks, hierarchically the four supporting variables are below it, which means that employee trust can be created if the four variables below (Figure 2) must be fulfilled properly.

\section{CONCLUSION}

Now it can be seen clearly, it turns out that the five independent variables which are Abraham $\mathrm{H}$. Maslow's hierarchical variables of needs and Hezberg's maintenance variables have an influence on the employee loyalty variable. This means that the physiological, security and safety, social, selt esteem, and self actualization variables which are Maslow's hierarchical fulfillment theory and Herzberg's two-factor theory of maintenance are proven to be related and have a role in the employee loyalty variable in the company (bank). This means that as long as the five independent variables can be fulfilled properly in accordance with employee expectations, it can be ensured that the condition of employee self-loyalty is well maintained. Because hierarchically, the needs and expectations of employees can be met gradually in the long term, this is a stimulation in an effort to improve the value of employee satisfaction with their basic needs. Based on the results of the test sample in one workplace, it shows that the motivation variables of Maslow and Herzberg show a positive and linear relationship with the internal conditions of employees, this a sense of the strength of loyalty. However, these results are not sufficient, it is still necessary to carry out the same testing in other workplaces of a different type of company. To prove whether the motivation variable can really maintain a sense of loyalty on an ongoing basis if the motivation needs of employees are met naturally and humanely, it is necessary to estimate the next stage in different situations and times. If testing is applied in many companies and the results are always positive, then Maslow's need for motivation and the need for maintenance motivation from Herzberg are only believed to have a positive role and contribution to hygiene or maintenance of employee loyalty. Actually, the relationship between the company and employees is a positive reciprocal relationship and is maintained on an ongoing basis to bring balanced benefits to both parties, without anything that can interfere with the relationship in the long term as long as the company is established and as long as the employees still have the desire to work. at the company. Of course this is not easy, because the internal and external environmental conditions of the company can change against the will of both parties. For that we need a method or method so that the relationship can run properly and benefit both parties between the company and the employees who work. The need for motivation for employees in the context of any theory is a normal and reasonable need. The company has created or designed a series of rules internally to maintain these conditions. Although sometimes there are deviations that sometimes occur unilaterally that cannot be denied or avoided. If this happens it will damage the harmony between the sense of loyalty of employees and the interests of the company that have been outlined previously. In order not to occur all forms of disturbances and irregularities, 
especially in the harmonious relationship between leaders and employees in a condition of maintaining employee loyalty, because if the conditions that occur every day are not mutually beneficial it will easily appear counter-productive conditions. Leaders value and respect employees, on the other hand, employees also do the same for all levels of leadership in the company.

Acknowledgments: We are happy to express our gratitude to the research team who have worked well together, so that all activities and actions in the research process can be completed properly. We hope that in the future, we will continue to be successful in better cooperation in other researches.

Conflicts of Interest: There was no conflict of interest in the writing of this article, either between fellow authors or with outsiders as research partners consisting of ten banks with 250 employees.

\section{REFERENCES}

Andriani, D., Purwana, D., \& Susita, D. (2020). Analysis Of Factors That Effect Lecturer Productivity Producing International Scientific Article In Private University: Motivation As A Moderating Variable. IJHCM (International Journal of Human Capital Management), 4(1), 87-107. https://doi.org/10.21009/IJHCM.04.01.08

Anna-Maija Lämsä; Terttu Savela., (2019), The effects of leadership development on women's career success, International Journal of Human Resources Development and Management, (19)1, pp. 21-36, DOI: 10.1504/IJHRDM.2019.097055

Dessler. Gary, (1992), Manajemen Personalia, Terjemahan, Edisi Ketiga, Erlangga, Jakarta.

Dharma, Agus, (1997). Manajemen Loyalitas, Pedoman Praktis Bagi Para Penyedia Untuk Meningkatkan Loyalitas. CV. Rajawali, Jakarta.

Dr. M.G. Bhaskar, Dr. B. Sahana. (2020). Language As An Integral Part Of Emotional Intelligence Management. International Journal of Advanced Science and Technology, 29(12s), 398 402. Retrieved from http: //sersc.org/ journals/index.php/ IJAST/article/view/22046

Dr. Naif Dalish N Alanazi, Dr.Aznan Bin Che Ahmad. (2020). The Effect Of Emotional Intelligence On The Academic Adjustment With Hearing Impairment Students In Saudi Arabia. International Journal of Advanced Science and Technology, 29(12s), 78 - 93. Retrieved from http://sersc.org/journals/index.php/IJAST/article/view/21910

Flippo, Edwin B, (1992), Manajemen Personalia, Jilid II, Terjemahan, Erlangga, Jakarta.

Gay, (1995), Regresi Linier Sebagai Alat Pengukuran dan Evaluasi, Edisi kedua, Terjemahan, Erlangga, Jakarta.

Hadi, Sutrisno, (1997). Metode Research, Jilid 1, Andi Offset, Yogyakarta.

Hamonangan Ismail, D., Asmawi, M., \& Widodo, S. E. (2020). The Effect of Organizational Culture, Leadership Style, and Trust to Organizational Commitments of LP3I Polytechnic Jakarta Lectures. IJHCM (International Journal of Human Capital Management), 4(1), 1625. https://doi.org/10.21009//JHCM.04.01.02

Handoko, T. Hani, (1992), Manajemen Personalia dan Sumber Daya Manusia, Edisi Kedua, Penerbit: BPFE. Yogyakarta. 
Handoko, T. Hani, (1992), Manajemen Personalia dan Sumber Daya Manusia, Edisi Kedua, Yogyakarta.

Srikanth, P.B. \& Jomon, M. G., (2020), Developing managerial competencies: integrating work design characteristics and developmental challenge, The International Journal of Human Resource Management, (31)22, pp. 1-26. https://doi.org/10.1080/09585192.2018.1474937

Hyeonjoo, Kim., (2020), Analysis of Diversity on Work Place for Human Resource Management, Global Journal of Human Resource Management, (8)4, pp. 24-31

Kenneth N, Wexley dan Garry A. Yuke, (1990). Perilaku Organisasi Perusahaan dan Psikologi Personalia, Terjemahan, Bina Aksara, Jakarta.

Maslow, H. Abraham, (1994), Motivasi dan Kepribadian, Jilid 1, PT. Pustaka Binaman Pressindo, Jakarta.

Ms. Rekha. R., Dr.V.Senthilkumar,. (2020). A Study On Career Growth And Enhancement Of Employees In Pharmaceutical Companies With Special Reference To Trivandrum City. International Journal of Advanced Science and Technology, 29(12s), 529 - 534. Retrieved from http://sersc.org/journals/index.php/IJAST/article/view/22222

N.Meenakshi \& Dr.Vijayakumari Joseph. (2020). Impact of Human Capital Development on Work Quality. International Journal of Advanced Science and Technology, 29(8s), 950 - 958. Retrieved from http://sersc.org/journals/index.php/lJAST/article/view/10862

Nadler dan Lawler, (1994). Penelitian Motivasi dan Loyalitas. Cetakan kedua, Terjemahan, Erlangga, Jakarta.

Porter, Lawler, (1995). Manajemen Personalia, Edisi Kedua, Terjemahan, Erlangga, Jakarta.

Ranupandojo, H. \& Suad Husnan, (1993), Manajemen Personalia, Edisi Keempat, BPFE, Yogyakarta.

Reksohadiprojo, Sukanto dan T. Hani Handoko, (1992), "Organisasi Perusahaan,

Siagian, P. Sondang, (1998). Manajemen Sumber Daya Manusia, Bumi Aksara, Jakarta.

Sudrajat, M, SW, (1998), Mengenal Ekonometrika Pemula, Cetakan Pertama, Armico, Bandung.

Sugiyono, (2015), Memahami Penelitian Kualitatif, Alfabeta, Bandung 